


\section{De betekenis van mestverwerking in een circulaire economie}

Geert Woltjer en Marie-José Smits

Dit onderzoek is uitgevoerd door Wageningen Economic Research in opdracht van en gefinancierd door het ministerie van Landbouw, Natuur en Voedselkwaliteit, in het kader van het Kennisbasis onderzoeksthema 'Biobased Circular Economy' (projectnummer KB-26-010-005)

Wageningen Economic Research

Wageningen, mei 2019

NOTA

2019-029 
Geert Woltjer en Marie-José Smits, 2019. De betekenis van mestverwerking in een circulaire economie. Wageningen, Wageningen Economic Research, Nota 2019-029. 24 blz.; 0 fig.; 0 tab.; 28 ref.

Wat is de rol van mestverwerking bij de transitie naar een circulaire economie? Hiertoe is het allereerst van belang om een helder beeld te krijgen van wat mestverwerking is en hoe het (mest)beleid hier invloed op heeft. De huidige mestverwerking past binnen een systeem dat er vooral op is gericht om huidige problemen op te lossen. Het is echter de vraag of er een rol is voor mestverwerking als de transitie naar een circulaire economie verder gevorderd is en, zo ja, wat die rol dan is.

What is the role of manure processing in the transition to a circular economy? To this end, it is first of all important to get a clear picture of what manure processing is and how (manure) policy influences this. Current manure processing fits within a system that is primarily focused on solving current problems. However, the question is whether there is a role for manure processing if the transition to a circular economy is more advanced and, if so, what that role is.

Trefwoorden: circulaire economie, mestverwerking, kringlooplandbouw, transitie

Dit rapport is gratis te downloaden op https://doi.org/10.18174/475439 of op www. wur. nl/economicresearch (onder Wageningen Economic Research publicaties).

(C) 2019 Wageningen Economic Research

Postbus 29703, 2502 LS Den Haag, T 07033583 30, E communications.ssg@wur.nl, www.wur.nl/economic-research. Wageningen Economic Research is onderdeel van Wageningen University \& Research.

\section{(cc) BY-NC}

Dit werk valt onder een Creative Commons Naamsvermelding-Niet Commercieel 4.0 Internationaallicentie.

(C) Wageningen Economic Research, onderdeel van Stichting Wageningen Research, 2019 De gebruiker mag het werk kopiëren, verspreiden en doorgeven en afgeleide werken maken. Materiaal van derden waarvan in het werk gebruik is gemaakt en waarop intellectuele eigendomsrechten berusten, mogen niet zonder voorafgaande toestemming van derden gebruikt worden. De gebruiker dient bij het werk de door de maker of de licentiegever aangegeven naam te vermelden, maar niet zodanig dat de indruk gewekt wordt dat zij daarmee instemmen met het werk van de gebruiker of het gebruik van het werk. De gebruiker mag het werk niet voor commerciële doeleinden gebruiken.

Wageningen Economic Research aanvaardt geen aansprakelijkheid voor eventuele schade voortvloeiend uit het gebruik van de resultaten van dit onderzoek of de toepassing van de adviezen.

Wageningen Economic Research is ISO 9001:2008 gecertificeerd.

Wageningen Economic Research Nota 2019-029 | Projectcode 2282100271

Foto omslag: Eddy Teenstra 


\section{Inhoud}

$\begin{array}{ll}\text { Samenvatting } & 5\end{array}$

1

$\begin{array}{ll}\text { Inleiding } & 6\end{array}$

2

$\begin{array}{ll}\text { Mestverwerking en mestbeleid } & 7\end{array}$

$\begin{array}{lll}2.1 & \text { Wat is mestverwerking? } & 7\end{array}$

$\begin{array}{lll}2.2 & \text { Mestbeleid } & 7\end{array}$

2.3 Conclusie $\quad 8$

$3 \quad$ Circulaire economie en kringlooplandbouw $\quad 9$

3.1 Circulaire economie $\quad 9$

3.2 Kringlooplandbouw 10

3.2.1 Beleidsvisie op Kringlooplandbouw 11

3.2.2 Technische Briefing Kringlooplandbouw 12

3.2.3 Klimaat 13

3.2.4 Zijn doelen zonder dwang te bereiken? $\quad 15$

3.3 Conclusie 16

$\begin{array}{llr}4 & \text { Mestverwerking en circulaire economie } & 17\end{array}$

$\begin{array}{llr}5 & \text { Conclusie } & 18\end{array}$

$\begin{array}{ll}\text { Literatuur en websites } & 19\end{array}$

Bijlage 1 Stromenschema mestverwerking in een circulaire economie 21 



\section{Samenvatting}

In Nederland wordt meer dierlijke mest geproduceerd dan er zinvol op het land kan worden gebruikt. Als gevolg daarvan moet de overtollige mest naar andere landen worden geëxporteerd. Vanwege de transportkosten leidt dit tot een negatieve mestprijs in Nederland. Door de voor export nuttige stoffen door middel van mestverwerking te scheiden van lokaal bruikbare stoffen en water, wordt het te exporteren volume lager en dalen dus de transportkosten. Met name van fosfaat is een overschot in Nederland. Het is daarom de vraag of het efficiënter is alleen een fosfaatmeststof of een meer compleet product zoals gekorrelde mest te exporteren. Dat laatste is aantrekkelijker voor degenen die de mest ontvangen omdat dan ook koolstof en andere waardevolle stoffen voor grondverbetering worden meegeleverd. Het nadeel is dat Nederland deze waardevolle stoffen dan kwijt is.

Het lijkt waarschijnlijk dat als kringlooplandbouw werkelijkheid wordt en/of het klimaatakkoord uitgevoerd gaat worden, de Nederlandse veestapel moet krimpen. In dat geval zal het mestoverschot verdwijnen, en lijkt de rol van mestverwerking grotendeels uitgespeeld, tenzij de kosten van mestverwerking, inclusief de milieueffecten daarvan, opwegen tegen de voordelen van meer precisielandbouw. Als dit het geval is, moet de prijs van kunstmest echter zo hoog zijn dat op dierlijke mest gebaseerde mestproducten concurrerend zijn.

Als in de circulaire economie andere reststromen met fosfaat, zoals rioolslib, worden gerecycled en dit een groot deel van de behoefte aan fosfaat voor de productie van kunstmest dekt, dan is het de vraag of er nog een rol is weggelegd voor met kunstmest vergelijkbare producten van mestverwerking.

Dit rapport komt tot deze conclusies op basis van een analyse van beleidsdocumenten rond de circulaire economie, kringlooplandbouw en mestverwerking, studies van Wageningen University \& Research, PBL, SER en de Raad voor de Leefomgeving en Infrastructuur, evenals opvattingen van LTO Nederland. 


\section{$1 \quad$ Inleiding}

Het doel van deze notitie is om de bedrijfseconomische analyses van mestverwerking (Van Wagenberg et al., 2018 en Van Wagenberg et al., 2019) gegeven de huidige situatie in het bredere kader van de circulaire economie te plaatsen. Hierbij wordt voortgebouwd op inzichten die verkregen zijn in het EUproject 'CIRCULAR IMPACTS' (Smits en Woltjer, 2018).

Vraagstelling: Wat is de rol van mestverwerking bij de transitie naar een circulaire economie (CE)?

Hiertoe is het allereerst van belang om een helder beeld te krijgen van wat mestverwerking is en hoe het (mest)beleid hier invloed op heeft (hoofdstuk 2). De huidige mestverwerking past binnen een systeem dat er vooral op is gericht om huidige problemen op te lossen. Het is echter de vraag of er een rol is voor mestverwerking als de transitie naar een circulaire economie verder gevorderd is, en zo ja, wat die rol dan is. Daarom wordt in hoofdstuk 3 besproken wat de circulaire economie is en zoomen we van daaruit in op de kringlooplandbouw. In hoofdstuk 4 wordt tot slot ingegaan op de mogelijke rol van mestverwerking binnen die circulaire economie.

\section{Afbakening:}

- In dit onderzoek beschrijven we de discussie omtrent de vraag in hoeverre mestverwerking bijdraagt aan de transitie naar een circulaire economie. Bij deze discussie hoort ook de beleidscontext, dus welke doelstellingen zijn er vanuit het beleid geformuleerd ten aanzien van circulaire economie en in hoeverre past mestverwerking dan in het transitiepad naar een circulaire economie. We beschrijven de discussie in hoofdlijnen, maar geven geen eindoordeel. Het gaat meer om een schets van de discussie, dan om een alomvattend antwoord.

- Omdat dit rapport een bredere context probeert te geven voor de risicoanalyses van circulaire innovaties rond nutriëntenmanagement in de varkenshouderij en melkveehouderij met het model MERIT-model (Van Wagenberg et al., 2019), beperken we ons tot nutriëntenstromen in varkenshouderij en melkveehouderij in Nederland.

\section{Methodologieontwikkeling:}

Met als startpunt het stromenschema van Van Wagenberg (2018) is een schema ontwikkeld waarin de relaties tussen (circulair) beleid en de nutriëntenstromen in de Nederlandse veehouderij worden aangegeven. Daarbij is het noodzakelijk in te gaan op de vraag wat circulaire economie in die context precies betekent. Dit schema is nog niet volledig uitontwikkeld, en is als bijlage in dit rapport opgenomen. 


\section{$2 \quad$ Mestverwerking en mestbeleid}

\subsection{Wat is mestverwerking?}

Omdat de totale hoeveelheid mest in Nederland hoger is dan wat er op het land kan worden toegediend, moet sinds 2014 een gedeelte van het mestoverschot van boeren verplicht worden verwerkt (PBL, 2017). Daarbij bedoelt men met mestoverschot de mest die de boer niet op eigen grond kwijt kan. De boeren met een mestoverschot zijn verplicht een bepaald percentage van het overschot buiten de Nederlandse landbouw af te zetten, om meer evenwicht binnen Nederland te creëren. Voor het vervoer, de opslag, het mengen en het verhandelen van de mest gelden regels om milieuschade te voorkomen en om besmettelijke dierziekten tegen te gaan. Bij mestverwerking hoort onder andere hygiëniseren van mest (voor transport naar het buitenland), het scheiden van mest in een dikke en een dunne fractie, het korrelen van mest of de dikke fractie van mest en processen zoals BioEcoSIM waarbij uit mest met kunstmest vergelijkbare producten gemaakt worden (BioEcoSIM, 2014).

De wettelijke definitie van mestverwerking is a) het verwerken volgens specificaties van een afnemer en b) het exporteren van fosfaat buiten de landsgrenzen (Vellinga et al., 2017, blz. 34).

Deze studie is een verbreding van de studie over mestverwerking door Van Wagenberg et al. (2019) waarin voor verschillende scenario's met het model MERIT worden doorgerekend, wat de kosten van mestverwerking zijn bij verschillende prijzen voor mestproducten, mineralen en transport. De relatieve rentabiliteit van de verschillende opties hangt onder andere af van de voerprijzen, de ruwe mestprijs, de vervoerskosten en de prijzen van geavanceerde mestproducten. Die laatste hangt weer samen met de prijzen van kunstmest.

Een belangrijk argument voor geavanceerde mestscheidingsmethoden is dat er in Nederland een fosfaatoverschot is, maar dat er bij gebruik van ruwe mest tot de maximaal toegestane hoeveelheid fosfaten er een tekort is aan stikstof, wat op het ogenblik wordt aangevuld met kunstmest. Daarom wordt er bij de simulaties met het model MERIT niet alleen gekeken naar mestverwerkingsmethoden, maar ook naar een optie om door middel van minder fosfor in het veevoer het fosfaatgehalte van de mest te verlagen. Daarnaast wordt gekeken naar internationaal transport. De verwerkingsopties die worden geanalyseerd zijn:

- Alleen scheiden

- Mest scheiden en dikke fractie composteren

- Mest scheiden en dikke fractie korrelen

- Mest direct korrelen

- Geavanceerde methoden:

- BioEcosiM

- RepeatGZ

Met betrekking tot fosfaatarm veevoer wordt geconcludeerd dat dit alleen eventueel aantrekkelijk is als de mest niet wordt verwerkt; bij mestverwerking gaan de opbrengsten van het eindproduct omlaag bij een lage mestprijs.

\subsection{Mestbeleid}

Vanuit het EU-beleid is de afgelopen decennia, wat betreft mest, met name aandacht besteed aan het beperken van emissies van stikstof en fosfaat. In 1991 is vanuit de EU de Nitraatrichtlijn uitgevaardigd (PBL, 2017). Hierin is opgenomen dat grond- en oppervlaktewater maximaal $50 \mathrm{mg}$ nitraat mag bevatten. Ieder land moet elke vier jaar een plan maken waarin wordt aangegeven hoe ze de nitraatrichtlijn gaan implementeren. De Nederlandse uitwerking van de Nitraatrichtlijn is vastgelegd in de Meststoffenwet met daaraan gerelateerde besluiten en uitvoeringsregelingen. Gebruiksnormen spelen 
een belangrijke rol binnen de meststoffenwet. Er zijn drie gebruiksnormen voor de Nederlandse boer: 1) voor dierlijke mest uitgedrukt in stikstof, 2) voor totale hoeveelheid stikstof (voor alle meststoffen), en 3) voor totale hoeveelheid fosfaat (voor alle meststoffen). Naast deze gebruiksnormen zijn er ook gebruiksvoorschriften die beschrijven hoe de mest toegepast moet worden.

Vanuit de Nitraatrichtlijn is bepaald dat boeren maximaal $170 \mathrm{~kg}$ stikstof van dierlijke mest per hectare mogen uitrijden. In een aantal EU-landen, waaronder Nederland, kunnen boeren gebruikmaken van 'derogatie'. Dit betekent dat Nederlandse boeren, onder bepaalde voorwaarden, meer dierlijke mest mogen uitrijden op grasland dan de Nitraatrichtlijn toestaat. Dit mag omdat op veel Nederlands grasland de groeiperiode lang is, waardoor er relatief veel stikstof wordt opgenomen.

Om te voorkomen dat Nederland te veel fosfaat op het land brengt, is door de EU voor de derogatie als eis gesteld dat er een maximum hoeveelheid fosfaat mag worden geproduceerd. Om niet door het fosfaatplafond heen te gaan gelden sinds 2006 voor varkens, kippen en kalkoenen dierproductierechten, maar voor melkvee was er geen restrictie meer na het afschaffen van de melkquota. Daarom is er in 2017 een fosfaatreductieplan opgesteld. Een stukje van het plan loopt via minder fosfaatrijk voer waardoor de mest minder fosfaat bevat, maar het grootste deel van het probleem wordt opgelost door het per 1 januari 2018 geldende stelsel van fosfaatrechten. Fosfaatrechten bepalen hoeveel fosfaat iedere melkveehouder mag produceren, en deze hoeveelheid wordt bepaald door het aantal dieren (gewogen naar soort).

De bedoeling is dat melkveehouders in principe het ruwvoer van hun grond halen en de mest daar ook zo veel mogelijk kwijt kunnen. Daarom is in 2015 het stelsel Verantwoorde groei melkveehouderij ingevoerd dat per 1 januari 2018 als de Wet Grondgebonden Groei Melkveehouderij is opgenomen in de Mestwet (RVO, 2018). Deze geldt voor melkveehouders die zijn gegroeid sinds 2013, en die een beperkte hoeveelheid grond hebben. Deze wet is bedoeld om te voorkomen dat de melkveehouderij zonder grond kan groeien.

Tot slot zijn er allerlei regels rond opslag, transport, mengen en verhandelen van mest. Het effect van alle maatregelen samen is dat Nederland met betrekking tot fosfaat nu bijna een evenwichtsbemesting heeft met een overschot van slechts 1-3 kg per hectare in 2014-2016 (Eurostat, 2018; Smits en Woltjer, 2018). Dit betekent niet dat het fosfaatprobleem vanuit milieuoogpunt daarmee opgelost is, omdat fosfaat die in het verleden is opgehoopt in de grond nog steeds kan uitspoelen en daarmee de wateren kan bevuilen.

Dankzij de nitraatrichtlijn worden nutriënten uit mest al veel nuttiger gebruikt dan in het verleden (verbieden overbemesting) en zijn emissies al flink teruggedrongen. Maar er is nog steeds te veel uitspoeling van stikstof en fosfor. PBL (2017) suggereert dat het misschien zinvol kan zijn om in gebieden waar meer dan voldoende fosfor in de grond zit minder met fosfor te bemesten dan wat de planten gebruiken, waardoor de voorraad fosfaat in de grond gaat afnemen (uitmijnen). Met name in de buurt van natuur en waterwingebieden kan deze maatregel zinvol zijn.

\subsection{Conclusie}

Het mestbeleid is gericht op het beperken van water- en luchtvervuiling door dierlijke mest en drijfmest. Gegeven dat de huidige mestproductie in Nederland groter is dan wat op het land gebruikt kan worden, ontstaat er een noodzaak tot mestverwerking. Om mestexport mogelijk te maken moet namelijk voldaan worden aan internationale regels, en dat betekent dat mest bewerkt moet worden voordat het geëxporteerd kan worden. Hygiëniseren is daarbij de minimale bewerking.

Omdat er een beperking is op het gebruik van mest, moet het overschot afgevoerd worden. De negatieve prijs voor mest die hieruit ontstaat bepaalt mede de economische haalbaarheid van verschillende typen mestverwerking. Mest verwerken kost geld, maar door de negatieve prijs van mest kan dit toch winstgevend zijn. Mestverwerking kan bijvoorbeeld transportkosten verlagen. Bovendien kan de wijze van mestverwerking invloed hebben op de uitstoot van methaan en lachgas, en daarmee ook op de milieukwaliteit. 


\section{Circulaire economie en kringlooplandbouw}

\subsection{Circulaire economie}

Er zijn verschillende definities van een circulaire economie (CE) in omloop. Hier volgen enkele definities van vooraanstaande instanties.

Ellen MacArthur Foundation:

'What is a circular economy? Looking beyond the current take-make-dispose extractive industrial model, a circular economy aims to redefine growth, focusing on positive society-wide benefits. It entails gradually decoupling economic activity from the consumption of finite resources, and designing waste out of the system. Underpinned by a transition to renewable energy sources, the circular model builds economic, natural, and social capital. It is based on three principles: design out waste and pollution, keep products and materials in use, regenerate natural systems. ${ }^{1}$

Europese Commissie:

'In a circular economy, the value of products and materials is maintained for as long as possible. Waste and resource use are minimised, and when a product reaches the end of its life, it is used again to create further value. This can bring major economic benefits, contributing to innovation, growth and job creation.' ${ }^{2}$

Rijksbrede programma Nederland circulair in 2050:

'In de circulaire economie verdwijnt het afval zoals we dat nu kennen. Afval is dé nieuwe grondstof. Vrijwel alles dat we straks gebruiken, wordt steeds opnieuw gebruikt. In een circulaire economie stappen we dus af van de lijn "produceren, consumeren en daarna weggooien". We maken de cirkel rond. Zo sparen we behalve onze grondstoffen ook het milieu, verminderen we onze $\mathrm{CO}_{2}$-uitstoot en stimuleren we innovatie, nieuwe bedrijvigheid en werkgelegenheid. ${ }^{3}$

Raad voor de Leefomgeving en Infrastructuur:

'In een circulaire economie worden grondstoffen langer en hoogwaardiger (streven naar oneindig hergebruik) in de keten gehouden, in plaats van afgedankt na (eenmalig) gebruik - zoals in het huidige lineaire systeem. Dat betekent economisch waardebehoud én waardecreatie en er treden minder schadelijke milieueffecten op.' ${ }^{4}$

Uit bovenstaande definities halen we drie aspecten die belangrijk zijn voor een CE. In een CE is het belangrijk dat:

1. grondstoffen langer benut worden door het sluiten van kringlopen (om uitputting van grondstoffen te voorkomen)

2. verliezen naar de omgeving, zoals emissies naar lucht, water en bodem, worden geminimaliseerd (om milieuschade te voorkomen) en

3. materialen en reststromen zo lang mogelijk hun waarde behouden (om downcycling te voorkomen).

1 https://www.ellenmacarthurfoundation.org/circular-economy/concept

2 https://ec.europa.eu/growth/industry/sustainability/circular-economy_en

3 https://www.circulaireeconomienederland.nl/rijksbreed+programma+circulaire+economie/default.aspx

4 Raad voor de Leefomgeving en Infrastructuur (2015), blz. 9) 
Mede op basis van het laatste aspect wordt in enkele van de voorgaande omschrijvingen geconcludeerd dat de circulaire economie positief is voor groei en werkgelegenheid, maar daar is a priori geen enkele reden voor omdat het langere waardebehoud over het algemeen ook kosten met zich meebrengt en macro-economische werkgelegenheid door heel andere factoren wordt bepaald dan arbeidsintensiteit (CPB, 2018; Woltjer, 2018).

CE is geen doel op zich. Het doel is verduurzaming van de economie, met name door het verminderen van het gebruik van grondstoffen en vermindering van emissies. Bij het economische belang voor vermindering van het gebruik van grondstoffen zijn overigens wel vraagtekens te stellen, omdat wanneer schaarste optreedt er via prijsverhoging vanzelf gezocht gaat worden naar alternatieven, en omdat ook het idee dat de afhankelijkheid van een beperkt aantal aanbieders tot grote problemen leidt in de praktijk alleen gedurende korte perioden optreedt (CPB, 2018).

Er wordt vaak betoogd dat reststromen die in een lineaire economie als afval worden gezien en geld kosten om op te ruimen, in een CE waardevolle input voor productieprocessen worden. Dit is echter verre van zelfsprekend. Het transformatieproces geeft ook kosten en kan ook emissies veroorzaken. Het is een grote ontwerpuitdaging om processen en producten zodanig te ontwerpen dat ze zo circulair mogelijk zijn en het is zeker niet zo dat elk circulair proces geen meerkosten geeft of nettomilieubaten geeft. Alleen al door de tweede wet van de thermodynamica is het niet mogelijk om waarde volledig te behouden, en daarom bestaat een volledig circulaire economie niet.

De beleidsambitie is Nederland circulair in 2050. Eind september 2016 is het 'Rijksbrede Programma Circulaire Economie' gelanceerd, waarin het kabinet de ambitie heeft geformuleerd om Nederland in 2050 samen met maatschappelijke partners circulair te maken:

'Het Rijksbrede programma circulaire economie richt zich op de ontwikkeling naar een vóór 2050 te realiseren circulaire economie. De ambitie van het kabinet is om samen met maatschappelijke partners in 2030 een (tussen) doelstelling te realiseren van $50 \%$ minder gebruik van primaire grondstoffen (mineraal, fossiel en metalen) ${ }^{5}$

CE kan gezien worden als een middel om duurzame economie of groene economie te realiseren, door uit te gaan van minimaliseren van grondstofgebruik, en van emissies. Het doel daarbij is het in stand houden van natuur en natuurlijk kapitaal. Het legt het accent op het belang van langdurig en waardevol gebruik van grondstoffen en het minimaliseren van het gebruik van uitputbare grondstoffen. En met dit accent geeft de circulaire economie een focus op een heel scala van maatregelen om de economie te verduurzamen.

\subsection{Kringlooplandbouw}

Kringlooplandbouw is een onderdeel van die circulaire economie. Het in stand houden van het natuurlijk kapitaal 'vruchtbare grond' speelt daarbij een belangrijke rol naast het verminderen van het gebruik van kunstmest door het meer recyclen van nutriënten zoals fosfaat, niet alleen vanuit mest, maar ook vanuit riool, slachtafval en ander afval. Ook toename van gebruik van reststromen voor veevoer en voor een biobased economy valt onder de kringlooplandbouw. En door sommigen wordt ook de verandering van het consumptiepatroon naar meer duurzaamheid, die ten dele hand in hand gaat met een betere gezondheid, onder kringlooplandbouw geplaatst. Immers, kringlooplandbouw is een landbouw die natuurlijk kapitaal niet aantast, en consumptieverandering kan daarvoor noodzakelijk zijn.

Kringlooplandbouw krijgt veel accent in het huidige beleid. Daarom beginnen we met de visie van Carola Schouten, de minister van Landbouw, Natuur en Voedselkwaliteit (LNV). Dan gaan we verder in op de visie die bij WUR wordt ontwikkeld, en die als een technische briefing voor de Tweede Kamer is uitgewerkt. Deze visie gaat nog een stap verder dan die van het ministerie. Tot slot gaan we in op de relatie tussen klimaatbeleid en kringlooplandbouw, omdat mest en veehouderij een grote rol spelen bij

5 Ministerie van I\&M, 2016, blz 7. 
de uitstoot van broeikasgassen door de landbouw. Een recent rapport van de Raad voor de leefomgeving en infrastructuur (2018) geeft hierbij nuttige inzichten. Tot slot bespreken we kort de opvattingen van de boerenorganisatie LTO op dit rapport, en vatten we de belangrijkste punten samen.

\subsubsection{Beleidsvisie op Kringlooplandbouw}

September 2018 heeft het ministerie van LNV de visie 'Landbouw, natuur en voedsel: waardevol en verbonden' (LNV, 2018) uitgebracht. Kringlooplandbouw wordt gezien als een manier om de toekomst van de voedselvoorziening veilig te stellen door het voorkomen van uitputting van bodem, water en grondstoffen, en het bijdragen aan klimaatmitigatie. Er wordt een context geschetst waarin de landbouw door verlaging van kosten een belangrijke bijdrage aan de Nederlandse welvaart heeft gegeven. Dat ging echter ten koste van milieu, natuur en landschap. Tegelijkertijd is de afstand tussen boeren en burgers vergroot door verstedelijking, waardoor inspanningen van boeren onvoldoende worden gewaardeerd. Er wordt gewezen op heel veel initiatieven bij landbouw en visserij, zoals het Deltaplan Biodiversiteitsherstel en duurzaamheidscertificering van de visserij. Er wordt ook op gewezen dat boeren en vissers een gevangene zijn van het huidige productiesysteem.

De oplossing wordt gezien in de ondernemersvaardigheden van de boeren, maar ook in de andere deelnemers van het systeem. Zo wordt er bijvoorbeeld op gewezen dat supermarktketens en groothandel als afnemers van boeren veel macht hebben en boeren onder druk kunnen zetten.

In de beleidsvisie wordt betoogd dat we van een op kostprijsverlaging gerichte economie naar een economie gericht op het verlagen van grondstoffenverbruik moeten gaan. Impliciet wordt verondersteld dat het mogelijk is om instituties zo te organiseren dat degene die beslissingen nemen omtrent productie, uitgaan van grondstofgebruik minimaliseren in plaats van kostprijs minimaliseren. Alleen als de verlaging van het grondstoffenverbruik door de consument wordt gewaardeerd door een hogere prijs te betalen of de overheid maatregelen introduceert waardoor de verlaging van het grondstoffenverbruik voordelig wordt, zal het bedrijfsleven de doelstellingen aanpassen.

Een ander idee dat in de beleidsvisie naar voren komt is dat kringlopen zo lokaal mogelijk gesloten moeten worden. Ook dat is niet vanzelfsprekend vanuit de economische wetenschap gezien. Immers, de keuze waar te produceren is een kosten-batenafweging, en zelfs vanuit milieuoogpunt kan het voordeliger zijn om grotere kringlopen te hebben. Omdat tomaten in Marokko in de volle grond worden geteeld en in Nederland in kassen, kunnen tomaten uit Marokko energiezuiniger worden geproduceerd.

De kringlooplandbouw wordt gezien als een systeem waar in de eerste plaats reststromen in de keten worden gebruikt in de landbouw en waar goed bodembeheer plaatsvindt. Er wordt geen of heel weinig kunstmest gebruikt, wat de broeikasgasemissies en andere emissies vermindert.

De veehouderij heeft in deze visie een belangrijke rol om de nutriëntenkringloop op een zo laag mogelijk niveau te sluiten. Voor veevoer worden de kringlopen lokaal gesloten door verliezen zo veel mogelijk te voorkomen, veevoer zo veel mogelijk lokaal te telen, en gebruik te maken van rest- en bijproducten uit onder meer de humane voedingsindustrie.

Naast deze aspecten wordt er ook aandacht besteed aan duurzame en emissiearme stallen en veehouderijsystemen, inclusief verminderd antibioticagebruik doordat stal en voer gericht zijn op voorkomen van ziektes. Ook diervriendelijkheid en koeien in de wei worden genoemd.

Voor akkerbouw betekent de circulaire economie precisielandbouw, goed bodembeheer, en de wens om ziekten, plagen en onkruiden zo veel mogelijk mechanisch en ecologisch aan te pakken en alleen als het niet anders kan pas chemische middelen te gebruiken.

Kringlooplandbouw heeft een verbeterde relatie met de natuur. Vermindering aan emissies betekent minder negatieve impact op de natuur, terwijl het benutten van natuurlijke processen ingezet kan 
worden voor bijvoorbeeld biologische bestrijding. Natuurinclusieve landbouw sluit hier direct op aan, waarbij bij de kringlooplandbouw het accent meer ligt op het sluiten van kringlopen en bij natuurinclusieve landbouw meer op verantwoord omgaan met de natuur en natuurlijke processen.

Als de kringlooplandbouw de nieuwe uitdaging is, zal innovatie hierop gericht moeten worden. Als dit gebeurt, is de optimistische visie dat gecombineerd met de grote ervaring van Nederland deze kennis een belangrijk exportproduct zal worden om de wereldvoedselproblematiek te helpen oplossen via duurzame intensivering. ${ }^{6}$

Het is kenmerkend, maar ook verrassend, dat de rol van de overheid vooral wordt gezien als meedenkend en faciliterend. Het leggen van verbindingen tussen partijen speelt daarbij een belangrijke rol. Vertrouwen, respect, rekenschap geven van ons handelen, dat is de sleutel tot succes. Alleen als de omslag te traag gaat, wordt er gedacht aan regelgeving. Het kabinet vertrouwt op de kracht van de samenleving, niet de overheid, om de omslag te maken, en nodigt iedereen uit om mee te denken en initiatieven te nemen. Dat is verrassend, omdat het impliciet veronderstelt dat de omslag zonder veel kosten voor de directe betrokkenen kan worden gemaakt en dat de omslag dus niet via regelgeving en financiële prikkels hoeft te worden afgedwongen.

\subsubsection{Technische Briefing Kringlooplandbouw}

Een groep onderzoekers onder leiding van Martin Scholten heeft een briefing voor de Tweede Kamer over kringlooplandbouw gemaakt (Scholten et al., 2018) die is samengevat als achtergronddocument bij de Mansholtlezing van de WUR (WUR, 2018). Deze briefing gaat ten dele nog een stukje verder dan de minister. Er wordt accent op gelegd dat ook nutriënten uit afvalwaterzuivering kunnen worden gebruikt, en dat er geen grond voor veevoer gebruikt mag worden die niet ook voor akkerbouw gebruikt had kunnen worden. Dat laatste is een fundamentele stap verder dan alleen te eisen dat het voer zo lokaal mogelijk geproduceerd moet worden. Deze striktere eisen kunnen ertoe leiden dat de veehouderijsector moet inkrimpen. Alleen als het lukt om de omzetting van reststromen naar veevoer zo groot te laten worden dat dit alle veevoerimporten plus vermindering van het grondgebruik voor veevoer op akkerbouwgrond compenseert, hoeft de veehouderij niet in te krimpen.

De notitie begint met het definiëren van kringlooplandbouw als een poging verliezen van grondstoffen te minimaliseren door kringlopen binnen het landbouwsysteem zo veel mogelijk te sluiten. Dit wordt gerealiseerd door optimaal beheer en gebruik van landbouwgrond, grondstoffen en hulpstoffen, vermindering en voorkomen van verspilling van agrarische geproduceerde biomassa, en het optimaal verwaarden van reststromen (Rood et al., 2016). Daarnaast wordt als principe aangegeven dat geen veevoer geteeld mag worden op grond die geschikt is voor akkerbouw. Akkers moeten primair worden gebruikt voor het telen van voedsel voor mensen. Veel grasland bevindt zich echter op grond die niet bruikbaar is voor akkerbouw. Ook gewas- en voedingsresten kunnen voor veevoer worden gebruikt. Doordat vee in staat is om niet voor menselijke consumptie geschikte afvalproducten en grond te gebruiken voor de productie van waardevolle, eiwitrijke voedingsmiddelen, en daarbij ook nog mest voor de akkerbouw te produceren, heeft de veehouderij een belangrijke rol in de kringlooplandbouw.

Volgens de notitie begint kringlooplandbouw bij goed bodembeheer. Het verhogen van het organischestofgehalte speelt daarbij een rol. Beter gebruik van organische mest, verminderen van grondbewerking en eventueel een minder intensief bouwplan spelen daarbij ook een rol. Ook stikstofbindende gewassen kunnen een rol spelen. De verhoging van het organischestofgehalte zal ook tijdens het proces leiden tot binden van koolstof, en daarmee helpen het klimaatprobleem te verminderen.

De opties worden vervolgens samengevat. Het eerste onderdeel is dat akkerbouwgrond primair voor de productie van voedsel voor mensen wordt gebruikt, waarbij restproducten voor diervoer kunnen worden gebruikt. Er wordt daarbij zoveel mogelijk gebruik gemaakt van natuurlijke processen en precisielandbouw. Graslanden op grond die niet geschikt is voor akkerbouw kunnen - met slimme

\footnotetext{
6 Wat betreft exporten zit er overigens wel een spanning tussen de wens kringlopen zo veel mogelijk lokaal te laten zijn, en Nederland als netto-exporteur van landbouwproducten. Nederland gaat minder veevoer importeren, maar dus waarschijnlijk ook minder veehouderijproducten exporteren.
} 
begrazing, bemesting en grondbeheer die aansluit op natuurlijke processen - voor diervoer worden gebruikt. Agrarische biomassa die niet voor menselijke consumptie geschikt is en restromen kunnen ook voor diervoer of grondverbetering worden gebruikt, waarbij hygiënische risico's door beperkte bewerking kunnen worden voorkomen. Nutriënten kunnen ook uit afvalwater worden gerecycled voor bemesting en veevoer, terwijl dierlijke mest beter kan worden ingezet door de dikke en dunne fractie gescheiden te houden en eventuele verdere bewerking tot bijvoorbeeld compost. Ook insecten kunnen potentieel worden ingezet als diervoer, waarbij insecten ook een rol kunnen spelen in het beschikbaar maken van voedingsstoffen die anders niet voor menselijke of dierlijke voeding geschikt zouden zijn. Het gebruik van de andere soorten diervoer kan efficiënter als nieuwe rassen worden ontwikkeld die efficiënter met dit voer kunnen omgaan.

De veehouderij, in een systeem zoals hiervoor beschreven, betekent waarschijnlijk dat niet de hele wereldbevolking op dezelfde voet als nu in de rijke wereld via dieren in haar eiwitbehoeften kan voorzien. Van Zanten (2016) schat dat op wereldschaal ongeveer de helft van de eiwitbehoefte door dierlijke eiwitten kan worden voorzien in zo'n kringloopsysteem, maar dit soort cijfers zijn zeer onzeker. De noodzaak tot inkrimpen van de veehouderij kan echter ook van een heel andere kant dan de kringlooplandbouw komen, namelijk het klimaatbeleid.

\subsubsection{Klimaat}

In de in de vorige paragraaf besproken Technische briefing wordt een schatting gemaakt van de aan de Nederlandse landbouw gerelateerde broeikasgasemissies. De officieel bij de landbouw gerapporteerde emissies zijn ongeveer 19 Mton $\mathrm{CO}_{2}$-equivalenten, waarbij nog eens $23 \mathrm{Mton}^{\mathrm{CO}_{2}-}$ equivalenten in andere sectoren zoals energie of LULUCF (emissie uit veenbodems) worden gerapporteerd. In het buitenland worden 15 Mton $\mathrm{CO}_{2}$-equivalenten uitgestoten als gevolg van de Nederlandse landbouw, vooral omdat veevoer wordt geïmporteerd.

De Raad voor de leefomgeving en infrastructuur (2018) heeft recent een rapport uitgebracht waarin wordt geconcludeerd dat de Nederlandse veehouderij waarschijnlijk moet inkrimpen om in 2050 aan de klimaatdoelstellingen van Parijs te voldoen. De veehouderij veroorzaakt op het ogenblik ongeveer 18 Mton $\mathrm{CO}_{2}$-equivalenten, wat gelijk staat aan $10 \%$ van de broeikasgasuitstoot van Nederland. Ros en Daniëls (2017) schatten dat de veehouderij met de huidige veestapel in 2050 minimaal 10 Mton $\mathrm{CO}_{2}$-equivalenten produceert, het hele quotum dat PBL als consistent met de Parijs doelstellingen ziet (Koelemeijer et al., 2017). Dat zou betekenen dat de rest van Nederland volledig klimaatneutraal zou moeten zijn, wat vanuit een kostenperspectief zeer inefficiënt lijkt.

De Raad wijst er ook op dat de landbouw in sommige gebieden meer mineralen aan de grond toevoegt dan er worden opgenomen, waardoor mineralen zich ophopen in de bodem en uitspoelen naar gronden oppervlaktewater. Dit heeft tot gevolg dat Nederland de doelstellingen van de Europese Kaderrichtlijn Water niet haalt, en ook niet voldoet aan de Nitraatrichtlijn.

Een tweede milieuprobleem met de veehouderij is dat ammoniak uit mest zich verspreidt in de lucht, en niet alleen stank veroorzaakt, maar ook neerslaat in de omgeving. Dat leidt tot ophoping van stikstof in natuurgebieden, waardoor biodiversiteitsdoelen niet worden gehaald. Het Programma Aanpak Stikstof (PAS) heeft tot doel dit probleem te verminderen, maar dit heeft tot nu toe onvoldoende resultaat opgeleverd. Driekwart van de Nederlandse natuur heeft een te hoge stikstofdepositie (PBL, 2017a).

Een derde milieuprobleem heeft belangrijke gevolgen voor de volksgezondheid. De veehouderij leidt tot extra fijnstof in de lucht. Een gedeelte van de hiervoor besproken ammoniakuitstoot wordt in de lucht omgezet in fijnstof, terwijl de sector ook direct fijnstof genereert in de vorm van mestdeeltjes, en deeltjes van veren, huid en haren. Fijnstof tast de longen aan en beïnvloedt de volksgezondheid daarmee negatief.

Tot slot hebben van dier op mens overdraagbare ziekten zoals Q-koorts en vogelgriep zo nu en dan grote gevolgen voor de volksgezondheid en heeft het antibioticagebruik in de veehouderij tot gevolg dat resistentie van bacteriën tegen antibiotica toeneemt; ruim $10 \%$ van de menselijke infecties met 
resistente bacteriën lijkt gerelateerd te zijn aan de veehouderij (Van Cleef, 2016). Er is wel een redelijk effectief beleid om antibioticagebruik in de Nederlandse veehouderij te verminderen.

Op basis van het voorgaande, en met name vanwege de klimaatdoelstellingen, is inkrimping van de veehouderijsector volgens de Raad voor de leefomgeving en infrastructuur onvermijdelijk. Ze wijst erop dat inkrimping van de Nederlandse veehouderij betekent dat de productie naar elders wordt verplaatst, en dat dit misschien gebieden zijn waar de broeikasgasuitstoot groter is dan in Nederland. Ze wijst er echter ook op dat de gemiddelde broeikasgasuitstoot wat anders is dan de marginale broeikasgasuitstoot: het kan heel goed zijn dat de productie van de minst efficiënte bedrijven wordt overgenomen door de meest efficiënte bedrijven in het buitenland, waardoor de vermindering van de broeikasgasuitstoot veel minder is dan op basis van gemiddelden wordt berekend. Bovendien zal ook in de rest van de wereld aan klimaatdoelen moeten worden voldaan, wat betekent dat er ook in het buitenland restricties zijn op de grootte van de veehouderij. Uiteindelijk betekent het wereldwijde klimaatbeleid dat er beperkingen zijn op de grootte van de veehouderij in de wereld.

Wat betreft beleid beveelt de Raad voor de leefomgeving en infrastructuur allereerst aan om duidelijkheid te verschaffen. Dat voorkomt dat investeringsuitgaven achteraf waardeloos blijken te zijn (stranded assets) omdat ze gebaseerd zijn op verkeerde informatie. De raad suggereert ook om de regulering vooral te richten op de doelstellingen, dat wil zeggen broeikasgasuitstoot. Ze zijn ervoor om zowel rechten voor broeikasgassen als fosfaatrechten verhandelbaar te maken. De broeikasgasrechten moeten dan uitgebreid worden naar de hele sector, inclusief veevoerproductie, zodat overal met dezelfde prijs gerekend wordt. Om emissierechten te kunnen toedelen, is het essentieel dat de hoogte van de emissies bekend is. De Raad adviseert daarom dat bedrijven een verplichte emissieboekhouding bijhouden op basis van kengetallen. Dit laatste is essentieel, maar het betekent nog steeds dat de emissiehandel gebaseerd is op heel grove informatie en dat het systeem aanzienlijke transactiekosten geeft.

De Raad adviseert om emissierechten toe te kennen op basis van de dieraantallen in 2016, met een emissiefactor die verschillend is voor verschillende diersoorten. We kunnen op basis hiervan concluderen dat historische rechten bepalend zijn voor verdeling van de emissierechten. Boeren hoeven in deze visie dus niet te betalen voor het oorspronkelijk quotum. Er wordt ook aangevoerd dat het toekennen van emissierechten aan boeren bedrijfsbeëindiging financieel aantrekkelijker maakt, omdat de emissierechten een kapitaalwaarde vertegenwoordigen. Hoewel de Raad hier geen expliciete uitspraak over doet, lijkt het logisch om handel van emissierechten tussen de verschillende veehouderijsectoren mogelijk te maken. En nog een stap verder zou zijn om op zijn minst te zorgen voor consistentie tussen de waarde van emissierechten binnen de veehouderij en de kosten in andere sectoren.

De emissierechten zullen stimuleren tot investeringen van het bedrijfsleven in duurzame innovatie, maar gegeven de positieve externe effecten zou de overheid hierbij ook een rol kunnen spelen. En sommige van deze innovaties zullen leiden tot export van deze technologieën, wat ook in de notitie Schouten over circulaire economie wordt aangegeven. Het kan er misschien ook toe leiden dat meer natuurinclusieve en circulaire bedrijfsmodellen relatief aantrekkelijker worden, met name voor de melkveehouderij. Voor de veengebieden zou het ertoe kunnen leiden dat de grond wordt vernat en dat er hetzij andere producten zoals riet en wilgen verbouwd worden, hetzij dat er een veel extensievere veeteelt plaatsvindt (van Dijk et al., 2018). Bij een extensievere veeteelt zou er ook toegevoegde waarde in de vorm van natuurbeheer, waterberging, en sociale of recreatieve diensten kunnen worden gecreëerd.

Samenvattend zal, als we de visie van de Raad voor de leefomgeving en infrastructuur volgen, de veehouderijsector in Nederland vanwege het klimaatbeleid kleiner worden. Voor mestverwerking betekent dit waarschijnlijk dat de negatieve mestprijs verdwijnt, en dat daarmee het huidige verdienmodel voor mestverwerking, verlaging van de transportkosten van de nutriënten van mest waarvoor een overschot is, verdwijnt. 


\subsubsection{Zijn doelen zonder dwang te bereiken?}

De Raad voor de leefomgeving en infrastructuur ziet regelgeving en verhandelbare quota als de manier om inkrimping van de veehouderij te bewerkstelligen. De minister van LNV ziet vooral samenwerking als mogelijkheid om de circulaire doelen te bereiken. Een voorbeeld van zo'n samenwerkingsverband is de Uitvoeringsagenda Duurzame Veehouderij, een convenant, gesloten in 2009, tussen het bedrijfsleven, maatschappelijke organisaties en de overheid, om gezamenlijk te komen tot een 'in alle opzichten duurzame' veehouderij in 2023.

De Uitvoeringsagenda Duurzame Veehouderij (2009) is gericht op een systeemverandering van de gehele sector, met bijvoorbeeld aandacht voor innovatieve stallen, dierenwelzijn, maatschappelijke en landschappelijke inpassing, verbeteren van het perspectief van de ondernemer, en verantwoord consumeren. Er zijn 15 ambities geformuleerd, onder andere om geen mineralen uit mijnen meer te gebruiken (zoals fosfaatkunstmest), gebruik van fossiele energie uit te bannen, evenredig bij te dragen aan de klimaatdoelstellingen, en grond en water duurzaam te gebruiken. Er worden allerlei voorbeeldprojecten uitgevoerd, zogenaamde versnellingsprojecten, en een netwerk waarin aandacht is voor samenwerking, kennisdeling en signaleren en agenderen. Om de vorderingen van het convenant inzichtelijk te maken, is een Monitoring Verduurzaming Veehouderij (Bos et al., 2017) in het leven geroepen.

De SER (2016) is zeer kritisch over de vrijwilligheid in het convenant:

'De commissie roept het kabinet op om het bedrijfsleven het instrument van de Algemeen Verbindend Verklaring te laten benutten waar dit kan helpen verduurzaming te versnellen. Dit instrument is noodzakelijk voor ondersteuning van collectieve initiatieven voor verduurzaming die kwetsbaar zijn voor free rider gedrag.' (SER, 1016, blz 15).

Er wordt dus gepleit voor meer dwang, ook al komen de ideeën in eerste instantie voort uit het convenant zelf.

De Land- en Tuinbouworganisatie Nederland (LTO, 2018) is het niet eens met het standpunt van de Raad voor de leefomgeving en infrastructuur waar het gaat om de conclusie dat inkrimping van de veestapel, afgedwongen vanuit de overheid, waarschijnlijk nodig zal zijn. Daarnaast stelt de LTO dat de veehouderij

'ook een stevige bijdrage aan verlaging van de uitstoot van broeikasgassen zoals afgesproken in het klimaatakkoord van Parijs: door de productie van groene energie (wind, zon, biogas) bijvoorbeeld. Maar ook door precisielandbouw (minder brandstof voor trekkers) en minder kunstmest, wordt aan de uitstoot van $\mathrm{CO}_{2}$ als gevolg van het gebruik van fossiele energie, een aanmerkelijke bijdrage geleverd aan de Parijs doelen.'

Daarnaast is LTO van mening dat steeds meer boeren oog krijgen voor een circulaire economie:

'Koers zetten naar een (nagenoeg) circulaire veehouderij (gesloten kringlopen) met zo min mogelijke verliezen naar het milieu, is milieutechnisch, ecologisch en economisch in het belang van de Nederlandse landbouw. Verbeteren van de kwaliteit van de bodem door toevoegen van kwalitatief hoogwaardige dierlijke mest betekent onder meer een verbetering van de biodiversiteit, minder gebruik van gewasbescherming, betere waterhuishouding, makkelijker bewerken van de grond. Ook in dat opzicht zegt de RLI niets nieuws. Boeren hebben steeds meer aandacht voor deze aspecten van de bedrijfsvoering.' (LTO, 2018) 
De LTO is ook tegen het instellen van verhandelbare emissierechten:

'De voorstellen tot omvormen van het fosfaat- en dierrechtenstelsel, bijvoorbeeld, tot een stelsel van verhandelbare emissierechten, zullen kostprijsverhogend effect hebben en daarmee zal op ondernemersniveau minder geld beschikbaar zijn voor innovatie en verduurzaming. Bovendien is de kans groot dat dit leidt tot niet-gewenste schaalvergroting van de Nederlandse veehouderij. De Raad besteedt geen aandacht aan ongewenste neveneffecten van de voorgestelde maatregelen, bijvoorbeeld voor kostprijs en stoppende boeren. LTO Nederland is geen voorstander van dergelijke rechtensystemen.'

De LTO heeft dus net als de Nederlandse regering de indruk dat de noodzakelijke transitie zonder al te harde maatregelen mogelijk is, en dat kostenverhoging leidt tot minder financiële armslag van ondernemers voor investering in verduurzaming. Het convenant Uitvoeringsagenda Duurzame Veehouderij is ook op deze gedachte gebaseerd, maar zoals gezegd zijn bijvoorbeeld de SER, het CPB, en de Raad voor de leefomgeving en infrastructuur kritisch over de vraag of doelen zonder overheidsdwang bereikt kunnen worden.

\subsection{Conclusie}

In een circulaire economie worden grondstoffen zo lang mogelijk benut, worden verliezen naar de omgeving geminimaliseerd en behouden materialen en reststromen zo lang mogelijk hun waarde. Circulaire economie is geen doel op zich, maar een middel om een duurzame economie of groene economie te realiseren, dat wil zeggen een economie gebaseerd op het in stand houden van natuur en natuurlijk kapitaal. Het legt accent op het belang van langdurig en waardevol gebruik van nietuitputbare grondstoffen en het minimaliseren van het gebruik van uitputbare grondstoffen. Met dit accent geeft de circulaire economie een focus op een heel scala van maatregelen om de economie te verduurzamen.

Kringlooplandbouw past deze principes toe op de landbouw. Organische reststromen worden zo veel mogelijk benut, bijvoorbeeld voor veevoer en bemesting. Grond, water en grondstoffen worden zo efficiënt mogelijk gebruikt voor het produceren van voedsel, en verspilling wordt zo veel mogelijk voorkomen. Dit betekent bijvoorbeeld, zoals beschreven in de visie van Scholten et al. (2018) dat veevoer alleen geproduceerd wordt op grond die niet geschikt is voor de teelt van menselijke voedingsgewassen of van restproducten, en in de visie van het ministerie van LNV dat veevoer lokaal wordt geproduceerd (LNV, 2018). Dit betekent waarschijnlijk dat veehouderij een kleinere sector wordt in Nederland.

Dezelfde conclusie kan ook getrokken worden uit de consequenties van het klimaatakkoord van Parijs. De broeikasgasuitstoot van de veehouderij slokt in 2050 het hele quotum op als de sector niet inkrimpt, aldus de Raad voor de Leefomgeving en Infrastructuur (RLI, 2018). De Raad adviseert in lijn met de gebruikelijke economische inzichten om via beprijzing van broeikasgassen en fosfaat tot inkrimping van de sector te komen. Het ministerie van LNV en LTO willen echter in eerste instantie via vrijwillige maatregelen tot noodzakelijke aanpassingen komen. Het convenant Uitvoeringsagenda Duurzame Veehouderij is ook op deze gedachte gebaseerd, maar zoals gezegd zijn bijvoorbeeld de SER, het CPB, en de Raad voor de Leefomgeving en Infrastructuur zeer kritisch over de vraag of doelen zonder overheidsdwang bereikt kunnen worden. 


\section{$4 \quad$ Mestverwerking en circulaire economie}

De behoefte aan mestverwerking is ontstaan doordat er in Nederland meer mest beschikbaar komt dan er op een nuttige wijze verbruikt kan worden. De aanscherping van de regels voor het gebruik van dierlijke mest hebben ertoe geleid dat mest niet meer op de goedkoopste manier kan worden afgevoerd, namelijk door de mest op het land in de nabijheid van de veeboer te gebruiken. Het mestoverschot dat ontstond en de verplichting deze buiten de Nederlandse landbouw af te zetten leidden ertoe dat mest geëxporteerd moest worden, en dat is vanwege het grote gewicht en volume duur. Eenvoudige mestverwerking zoals het drogen van de mest is een manier om de transportkosten te verlagen. Het mestoverschot leidt er echter wel toe dat veehouders zo veel mogelijk mest goedkoop in de directe omgeving willen afzetten en daarom de grenzen van de wettelijke bemestingsregels opzoeken (of zelfs overschrijden).

In theorie kan regelgeving rond bemesting in combinatie met mestverwerking en transport van de waardevolle delen van de mest naar gebieden waar er behoefte aan is, ervoor zorgen dat de mest zinvol wordt gerecycled, op dezelfde manier als dit vroeger gebeurde in de directe omgeving. Dit leidt echter tot transportkosten en bewerkingskosten, inclusief het energieverbruik en overige grondstoffen die daarvoor nodig zijn. Vanuit dit perspectief zorgt mestverwerking ervoor dat de mest op een grotere regionale schaal kan worden gerecycled.

In hoofdstuk 3 is aangegeven dat kringlooplandbouw er waarschijnlijk toe leidt dat de veestapel in Nederland kleiner gaat worden. Ook het klimaatbeleid gaat daar waarschijnlijk toe leiden. Als de veestapel voldoende inkrimpt zodanig dat alle mest kan worden afgezet binnen Nederland, verdwijnt het mestoverschot, en daarmee ook de noodzaak tot mestverwerking ter verlaging van transportkosten. Mestverwerking is nu immers alleen rendabel met een negatieve mestprijs, en die zal verdwijnen als transport van mest over grote afstanden niet meer nodig is en de dierlijke mest lokaal weer als een waardevol onderdeel van bemesting wordt gezien.

Mest speelt een belangrijke rol in de visie op een circulaire economie en wordt gezien als een reststroom die zo goed mogelijk benut moet worden. Mestverwerking kan hierbij een rol spelen, ook zonder een mestoverschot, als het ertoe leidt dat nutriënten beter benut kunnen worden, emissies verminderen, of het uitrijden van de mest de grond minder beschadigt. Een technologie zoals ontwikkeld in BioEcoSIM (2014) heeft waarschijnlijk wat minder emissies tot gevolg en kan misschien leiden tot een betere opname van de nutriënten, maar leidt tot meer energiegebruik en gebruikt chemicaliën. Zo'n technologie heeft echter als voordeel dat er met kunstmest vergelijkbare mestproducten uitkomen, die potentieel precisiebemesting makkelijker maken. Als wetgevingsbarrières voor gebruik van bemestingsproducten gemaakt van dierlijke mest worden opgelost, waar al grote stappen voor worden gezet (LTO, 2018a), dan kunnen de met kunstmest vergelijkbare mestproducten die door geavanceerde mestverwerking worden geproduceerd, ook prijzen krijgen die vergelijkbaar zijn met die van kunstmest. Als kunstmest vervolgens door een belasting, door stijging van de prijs van broeikasgasemissies of door andere redenen veel duurder worden, kunnen de opbrengsten van de mestproducten uit mestverwerking stijgen en kunnen ze ook bij positieve mestprijzen misschien rendabel worden. Of dit het geval is, kan potentieel door een model zoals MERIT (Van Wagenberg et al., 2019) worden berekend.

In de circulaire economie is nog een andere dynamiek relevant voor de rentabiliteit van mestverwerking en dat is dat er veel meer andere reststromen gerecycled zullen worden. Als bijvoorbeeld fosfor uit afvalwater wordt gehaald, wordt er in Nederland al een groot deel van de behoefte aan fosfor uit kunstmest gedekt. Het is dan de vraag of er nog een rol is weggelegd voor met kunstmest vergelijkbare producten van mestverwerking. 


\section{$5 \quad$ Conclusie}

In de huidige Nederlandse situatie waarin de mestproductie groter is dan wat er zinvol op het land kan worden gebruikt, met name met betrekking tot fosfaat, moet er een oplossing worden gezocht voor het mestoverschot. Een gedeelte wordt op het ogenblik geëxporteerd naar met name Duitsland en Frankrijk, maar dat geeft milieuproblemen door transport en opslag, en de plaatsingsruimte in Duitsland wordt door de door de EU afgedwongen verscherping van het bemestingsbeleid kleiner, wat betekent dat de mest verder weg geëxporteerd moet worden. Dat maakt de kosten hoger, en dat resulteert in de dreiging dat de mestprijs nog verder negatief wordt.

De negatieve mestprijs creëert de mogelijkheden voor mestverwerking. Ruwe mest vervoeren is duur; bij mestverwerking worden de nutriënten waar een overschot van is uit de mest gehaald en kunnen daardoor tegen relatieve lage vervoerskosten naar gebieden gebracht worden waar ze wel nuttig zijn. De enige vraag hierbij is of alleen bijvoorbeeld fosfor vervoerd moet worden, of dat een meer compleet mestproduct zoals gekorrelde mest vervoerd wordt. Dat laatste is aantrekkelijker voor degenen die de mest ontvangen omdat dan ook koolstof en andere waardevolle stoffen voor grondverbetering worden meegeleverd. Het nadeel is dat Nederland dan deze waardevolle stoffen dan kwijt is.

Als de veestapel moet krimpen in het kader van kringlooplandbouw of het klimaatakkoord, dan lijkt de rol van mestverwerking grotendeels uitgespeeld, tenzij de kosten van mestverwerking, inclusief de milieueffecten daarvan, opwegen tegen de voordelen van meer precisielandbouw. Als dit het geval is, dan moet de prijs van kunstmest echter zo hoog zijn dat op dierlijke mest gebaseerde mestproducten concurrerend zijn. Het model MERIT kan een nuttige bijdrage leveren om te berekenen onder welke omstandigheden dat het geval is.

Als in de circulaire economie andere reststromen met fosfor worden gerecycled, en dit een groot deel van de behoefte aan fosfor kunstmest dekt, dan is het de vraag of er nog een rol is weggelegd voor met kunstmest vergelijkbare producten van mestverwerking. 


\section{Literatuur en websites}

BioEcoSIM (2014). BioEcoSIM factsheet. gedownload 7 feb 2019:

https://www.bioecosim.eu/images/20140422_BioEcoSIM_Factsheet.pdf.

Bos, A.P., D. Puente-Rodríguez, J.W. Reijs, G.F.V. van der Peet en P.W.G. Groot Koerkamp (2017). Monitoring verduurzaming veehouderij 1.0; Een eerste proeve van een Monitorings-systematiek voor de 15 ambities van de Uitvoeringsagenda Duurzame Veehouderij, met initiële resultaten voor drie diersectoren en een aantal keteninitiatieven. Wageningen Livestock Research, Report 1045. doi.org/10.18174/423671

Cleef, B.A.G.L. van (2016). MRSA in pig farms: human epidemiology. 's-Hertogenbosch: Uitgeverij BoxPress, beschikbaar via https://research.vu.nl/ws/portalfiles/portal/42157608/complete+dissertation. pdf

CPB (2018). Circulaire economie: economie en ecologie in balans. CPB Policy Brief.

Dijk, J. van, H. Runhaar, R. Verburg en M. Hekkert (2018). Innovatieve kennis genoeg, nu nog de toepassing, NRC Handelsblad, 4 december 2018, gastblog.

Eurostat (2018). Gross nutrient balance per hectare. Beschikbaar via https://data.europa.eu/euodp/en/data, variabele aei_pr_gnb.

Koelemeijer, R., B. Daniëls, P. Boot, P. Koutstaal, S. Kruitwagen, G. Geilenkirchen, M. Menkveld, J. Ros, G.J. van den Born, S. Lensink en M. van Hout, M. van (2017). Analyse regeerakkoord Rutte-III: effecten op klimaat en energie. Den Haag: PBL.

LNV (2018). Visie Landbouw, Natuur en Voedsel: Waardevol en Verbonden. Den Haag.

LTO (2018). RLI brengt geen nieuwe inzichten. http://www. Ito.nl/actueel/nieuws/10893133/RLIbrengt-geen-nieuwe-inzichten

LTO (2018a). Nieuwe Europees akkoord meststoffen is goede stap vooruit.

http://www.Ito. nl/actueel/nieuws/10896713/-Nieuwe-Europees-akkoord-meststoffen-is-goedestap-vooruit

Ministerie van I\&M (2016). Nederland circulair in 2050: Rijksbreed programma Circulaire Economie. Den Haag.

PBL (2017). Evaluatie Meststoffenwet 2016: Syntheserapport, Beschikbaar via:

http://www.pbl.nl/sites/default/files/cms/publicaties/pbl-2017-evaluatie-meststoffenwet-20162258_0.pdf.

Planbureau voor de Leefomgeving (2017a). Milieu- en ruimtelijke condities nog onvoldoende voor landnatuur. http://themasites.pbl.nl/balansvandeleefomgeving/jaargang-2017/themas/ natuur/trends-en-toestand-milieu-en-ruimtelijke-condities-landnatuur.

Raad voor de Leefomgeving en Infrastructuur (2015). Circulaire economie: van wens naar uitvoering. Den Haag.

Raad voor de leefomgeving en infrastructuur (2018). Duurzaam en gezond: samen naar een houdbaar voedselsysteem. Den Haag.

Rood, T., H. Muilwijk en H. Westhoek (2016). Voedsel voor de circulaire economie. Policy Brief, Planbureau voor de Leefomgeving.

Ros, J. en B. Daniëls (2017). Verkenning van klimaatdoelen, Policy Brief, PBL Planbureau voor de Leefomgeving.

RVO (2018). Mest. Geraadpleegd op 7-2-2019 van https://www.rvo.nl/onderwerpen/agrarischondernemen/mestbeleid/mest.

Scholten, M. et al. (2018). Wat mogen we verwachten van een circulaire voedselproductie gebaseerd op een kringlooplandbouw, in het perspectief van klimaat- en biodiversiteitdoelen?, Technische Briefing Kringlooplandbouw Notitie opgesteld op verzoek van de Tweede Kamer Commissie LNV.

SER (2016). Versnelling duurzame veehouderij. Advies 16/06. Oktober 2016. Den Haag.

Smits, M. en G.B. Woltjer (2018). Phosphorus Recycling from Manure: A Case Study on the Circular Economy. CIRCULAR IMPACTS Project, beschikbaar via: https://circular-impacts.eu/deliverables.

Uitvoeringsagenda Duurzame Veehouderij (2009). Gedownload via: https://mvonederland.nl/system/files/media/uitvoeringsagenda_duurzame_veehouderij_def.pdf. 
Vellinga, T., F. Leenstra, B. Bremmer en J. Tersteeg (2017). Kringlooptoets Mestverwerking. Wageningen Livestock Research, Rapport 1046.

Wagenberg, C.P.A. van, F. Greijdanus en H. Luesink (2018). Kosteneffectieve oplossing voor fosfaatprobleem met Nederlandse vleesvarkensmest, Wageningen: Wageningen Economic Research. Available at: https://www.wur.nl/upload_mm/0/6/7/644d00b0-b67b-435b-95c7d1fc14dc9243 2018-020 Wagenberg def.pdf.

Wagenberg, C.P.A, van, A.F. Greijdanus en H.H. Luesink (2019). Economische optimalisatie van de afzetketen voor varkens- en melkveemest; Scenarioanalyse met het MERIT-model. Wageningen, Wageningen Economic Research, Rapport 2019-051.

Woltjer, G. (2018). Methodologies for Measuring the Macroeconomic and Societal Impacts of the Circular Economy, CIRCULAR IMPACTS Project, beschikbaar via: https://circular-

impacts.eu/deliverables.

WUR(2018). Circular agriculture: a new perspective for Dutch agriculture, gedownload 20 dec 2018 via https://www.wur.nl/upload_mm/6/e/e/07a9b802-0bbe-4a7e-a2cb597236a0d359_Circular\%20agriculture\%20\%20A\%20new\%20perspective\%20for\%20Dutch\%20agriculture.pdf

Zanten, H.H.E. van (2016). Feed sources for livestock: recycling towards a green planet. PhD Wageningen University. 


\section{Bijlage 1 Stromenschema mestverwerking in een circulaire economie}

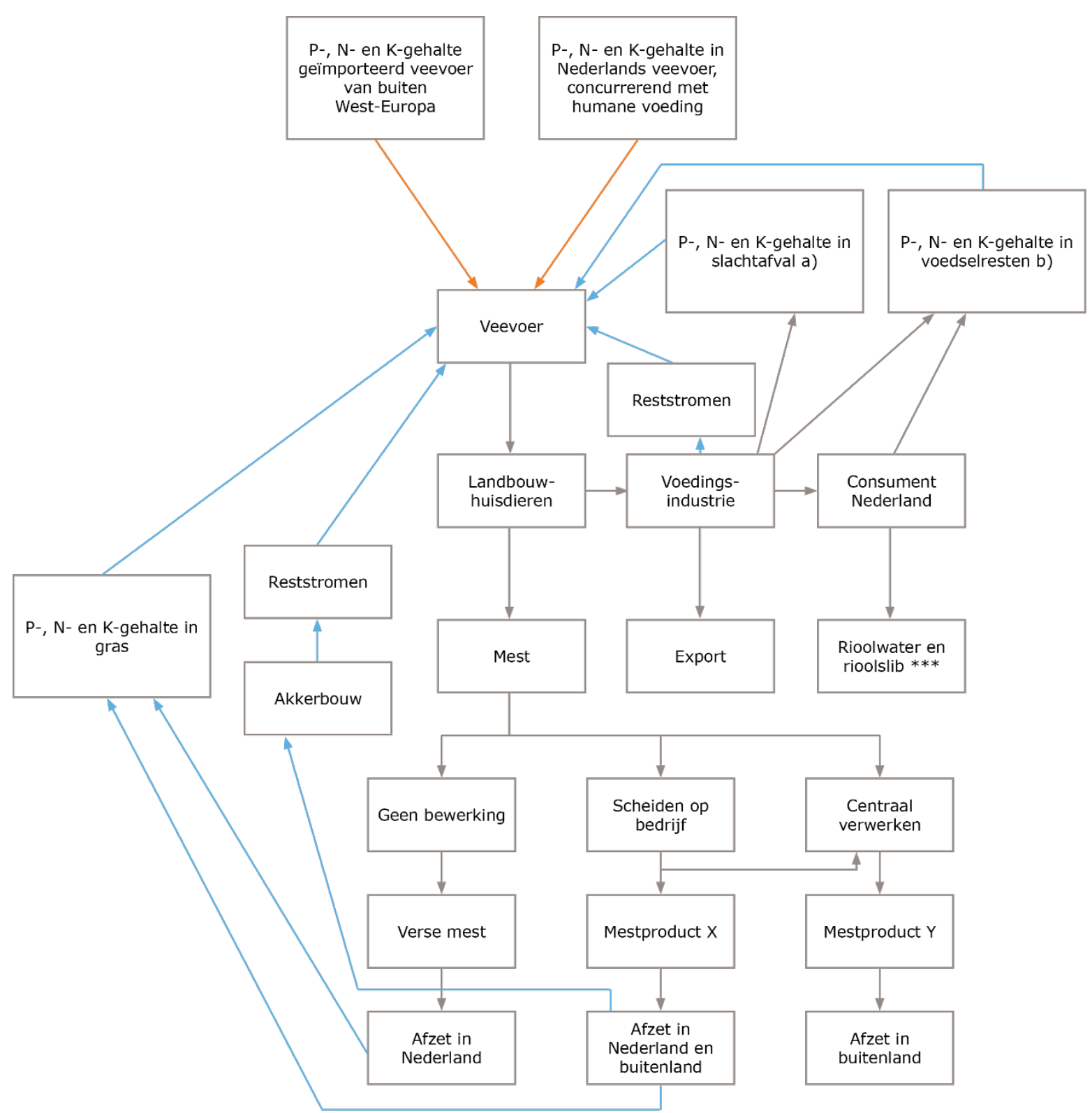

a) Slachtafval mag wettelijk (bijna) niet gebruikt worden in diervoeder sinds de BSE crisis. Door nieuwe technieken kunnen de risico's echter verminderd worden; b) Voedselresten mogen wettelijk (bijna) niet gebruikt worden in diervoeder. Door nieuwe technieken kunnen de risico's echter verminderd worden; c) Ook fosfaat uit rioolslib kan onder andere gebruikt worden voor veevoer: dit kan concurreren met fosfaat in mestverwerkingsproducten.

Het bovenstaande stromenschema is een uitbreiding van het schema in Van Wagenberg et al. (2018) en verder geïnspireerd op Scholten (2018), en is een begin van een methode om de kringloopeconomie en mestverwerking explicieter te koppelen. De nutriënten P (fosfaat), N (stikstof) en $\mathrm{K}$ (kalium) stromen via veevoer door naar dieren, mest, mestverwerkingsproducten, export, de consument in Nederland, riool, slachtafval, voedselresten, etc. In dit onderzoek focussen we op mestverwerking in het kader van circulaire economie; de focus ligt daarom op het onderste deel van dit schema. 
Het huidige veevoer komt grotendeels uit het buitenland (soja en granen). In een circulaire economie worden zo veel mogelijk reststromen gebruikt, bijvoorbeeld veevoer gemaakt van slachtafval en van voedselresten (uit voedingsindustrie, groot gebruikers en consumenten).

In een circulaire economie worden nutriënten uit mest zo efficiënt mogelijk gebruikt en hergebruikt om vervuiling door onbedoelde uitstoot en uitputting van grondstoffen te voorkomen. Bewerking van mest (bijvoorbeeld scheiden dikke en dunne fractie) kan bijdragen aan betere benutting van mest, maar mestverwerking kan ook tot doel hebben de mest goedkoper af te zetten in het buitenland.

Het schema kan worden gebruikt om aan te geven op welke plaatsen het beleid ingrijpt.

Beleid kan gericht zijn op:

A - consumptie

B - productie (veevoer, dieren)

C - mest (mestverwerking, mestgebruik)

Doel van het beleid kan zijn:

1 - emissies verminderen

2 - grondstofgebruik verminderen (bijvoorbeeld minder kunstmest)

3 - ondersteunen boeren (bijvoorbeeld door waarde behoud mest)

Wijze van beleid kan zijn:

I - technische eisen (bijvoorbeeld ten aanzien van samenstelling veevoer)

II - gericht op gedrag (bijvoorbeeld verboden rond mestgebruik)

III - ondersteunend beleid (financieel, organisatorisch, bijvoorbeeld ten behoeve van innovaties) 
Wageningen Economic Research Postbus 29703

2502 LS Den Haag

T 0703358330

Ecommunications.ssg@wur.nl

www.wur.nl/economic-research

Wageningen Economic Research NOTA

2019-029
De missie van Wageningen University \& Research is 'To explore the potential of nature to improve the quality of life'. Binnen Wageningen University \& Research bundelen Wageningen University en gespecialiseerde onderzoeksinstituten van Stichting Wageningen Research hun krachten om bij te dragen aan de oplossing van belangrijke vragen in het domein van gezonde voeding en leefomgeving. Met ongeveer 30 vestigingen, 5.000 medewerkers en 10.000 studenten behoort Wageningen University \& Research wereldwijd tot de aansprekende kennisinstellingen binnen haar domein. De integrale benadering van de vraagstukken en de samenwerking tussen verschillende disciplines vormen het hart van de unieke Wageningen aanpak. 



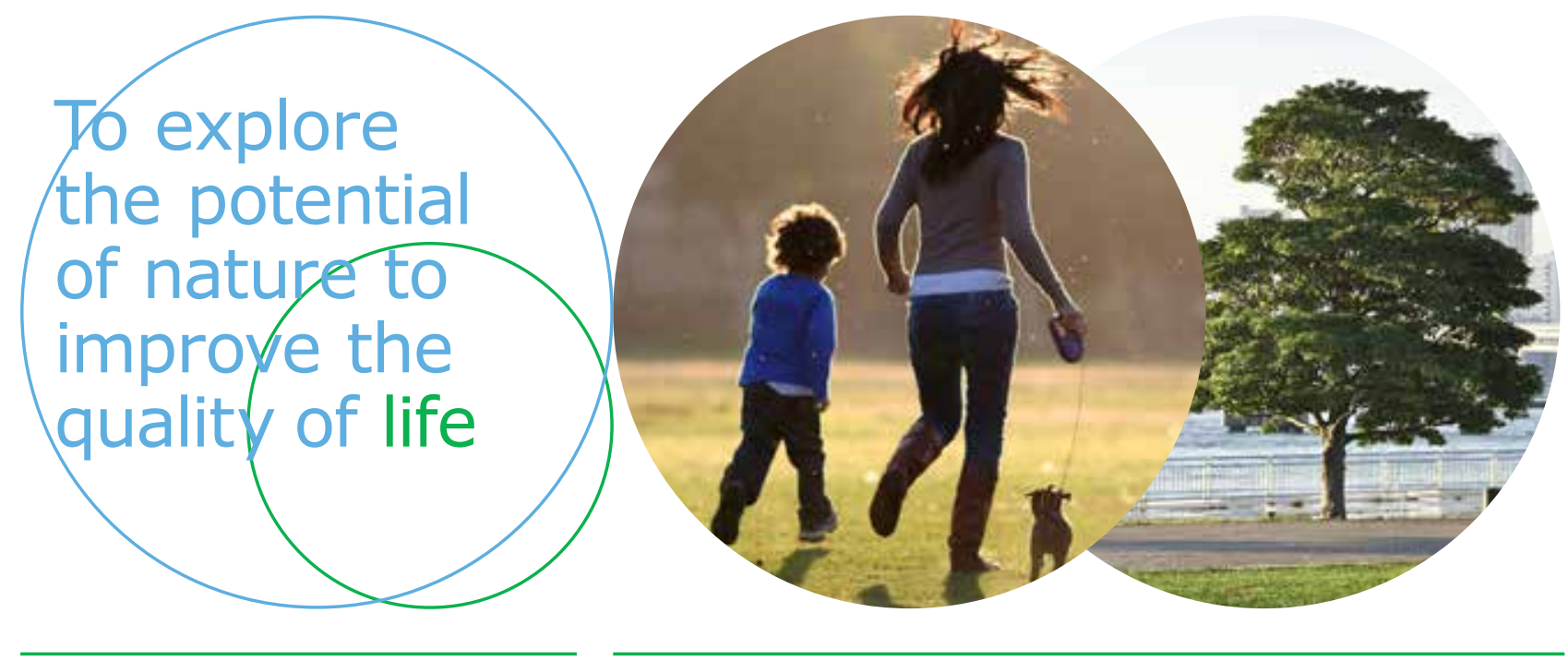

Wageningen Economic Research Postbus 29703

2502 LS Den Haag

E communications.ssg@wur.nl

$\mathrm{T}+31(0) 703358330$

www.wur.nl/economic-research

Nota 2019-029
De missie van Wageningen University \& Research is 'To explore the potential of nature to improve the quality of life'. Binnen Wageningen University \& Research bundelen Wageningen University en gespecialiseerde onderzoeksinstituten van Stichting Wageningen Research hun krachten om bij te dragen aan de oplossing van belangrijke vragen in het domein van gezonde voeding en leefomgeving. Met ongeveer 30 vestigingen, 5.000 medewerkers en 10.000 studenten behoort Wageningen University \& Research wereldwijd tot de aansprekende kennisinstellingen binnen haar domein. De integrale benadering van de vraagstukken en de samenwerking tussen verschillende disciplines vormen het hart van de unieke Wageningen aanpak. 